\title{
The Impact Of Pandemic Covid-19 On Online Learning Activities From April To July 2020 In Institut Stiami, Jakarta
}

\author{
Redjeki Agoestyowati ${ }^{\text {a,1,** }}$ \\ ${ }^{a}$ Institut Ilmu Sosial dan Manajemen STIAMI \\ ${ }^{1}$ redjeki.agoestyowati@gmail.com / redjeki@stiami.ac.id* \\ * corresponding author
}

ARTICLE INFO

\section{Article History}

Received

Revised

Accepted

Keywords

On-line Learning;

Teaching;

Activities;

Pandemic;

Covid-19

\begin{abstract}
Many people have known that Covid-19 has changed the world in all aspects. One of the aspect is education. It has made a lot of changing in transferring knowledge drastically, because lecturing was given online, attendance list was checked by program, examination was done by application. This research will describe about teaching and learning activities during the Pandemic of Covid 19 in Institut Stiami, Jakarta. Data collection was taken by interviewing some students by using zoom, google meet, WhatsApp, SSO (Single Sign On) of Institut Stiami or other Application. WhatsApp and Zoom are the application that often used in the Teaching and Learning Process. One of the biggest problem during online learning is about internet pulse or quota and connection is up and down sometimes. However, most of the students concluded that they enjoy learning online and during pandemic (Covid-19) and the teaching-learning activities ran quite well. During the lesson, some problem appeared such as technology, technical problem, internet connection, communication, etc., but all can be solved.
\end{abstract}

\section{INTRODUCTION}

The world is changing. Corona Virus has change the world, life style, economic situation, etc. There are many aspects have changed, even almost in all aspects, one of them is education. Since Covid-19 appeared in Jakarta, then there was a regulation from the government that people have to do social and physical distancing, avoid gathering, meeting people, then the government asked students to study from home and some teachers and lecturers teach from home. The government hoped that social distancing would decrease the spread of virus.

Institut Stiami, Jakarta is one of the campuses that follow the government rules about study from home or on-line learning. Technology has an important role to make all on-line teaching and learning activities work well. Students can use many different equipment for online learning such as smart phone, computer, laptop, etc and students must have Wi-Fi for internet connection or they have to use internet data to be able to join on-line learning.

During Pandemic, Lecturers teach from home, and it is called virtual learning (Computer Based Learning) by using many different media, such as WhatsApp, Zoom, G-meet or other application. Lecturers facilitate the students by giving some lessons and students listen to the Lecturers, so there will be interaction among them. In the end of the session, usually lecturers give them assignment and the students do it by themselves, or we can call it as an independent learning.

E-Learning or on-line learning becomes a common thing this time. People are forced to start doing distance learning since Corona Virus appeared in Indonesia. People are force to start doing PJJ or Pembelajaran Jarak jauh, which has some positive and negative aspects. Some example of the positive impacts are: 1) Students can communicate with their lecturers anytime, anywhere (flexi time), 2) Teaching and Learning activities can be done anytime; anywhere (flexible), 3) Independent Learning and students are more creative. On the other hand, it has negative impact, such as: 1) It is not as effective as offline learning, 2) It is not easy for some students to receive the material given by their lecturer, 3) Easy for the students not to attend the class during the session or they joined late 


\section{RESEARCH METHOD}

This research is descriptive qualitative, that is done to describe one variable or more. The data is taken by interviewing 5 students from 5 different classes of Institut Stiami by WhatsApp, and their answered will be written in the discussion

The following are some questions to the students:

1. Do you enjoy study from home? Why?

2. What application do Lecturers use for teaching and learning activities?

3. What is the best application for your class activities: WA, G-Meet, Zoom, Google Classroom or others?

4. What do you think about the application that is used in your class?

5. What are the positive and the negative aspect of learning on line?

6. Did the program run very well?

7. What Problem do you have during the class?

8. Any suggestions?

\section{DISCUSSION}

Most of them mentioned that the best way to learn on-line is by using WhatsApp because it is cheaper, easier and the voice is very clear. Teaching and learning online ran well.

Here are the answers from five students:

1. Student 1

a. Question 1: Yes, I enjoy studying from home because I can directly go home after working, and study from home.

b. Question 2: zoom dan G-meet, WA

c. Question 3: Zoom

d. Question 4: Zoom is good because we can see the lecturer's face.

e. Question 5:

Positive Aspect: Learning online means independent learning; I can be more creative and I understand the lesson quite easier if I compare with offline.

Negative Aspect: sometimes, internet connection is not good, so leacturer's voice cannot be listened well.

f. Question 6: Yes, very well

g. Question 7: Learning Accounting on-line is the most difficult but I try to understand and ask to my lecturer if I don't understand

h. Question 8: My problem in online learning is accounting lesson, but I always try to understand by asking so many questions to my lecturer.

Picture 1: Answer Sample of WA chat with a student of Institut Stiami

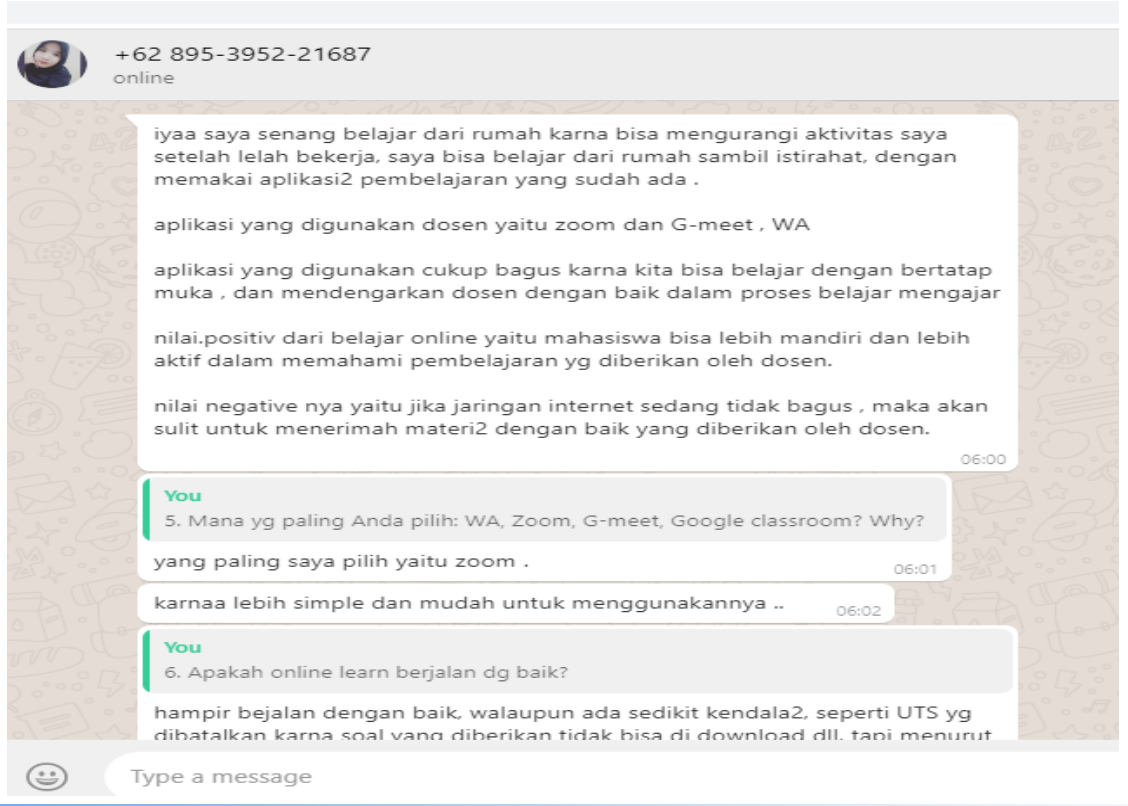


2. Student 2

a. Question 1: Yes, I do

b. Question 2: Zoom, SSO, WA

c. Question 3: WA and SSO

d. Question 4: Good

e. Question 5:

Positive Aspect: it doesn't cost much, enjoyable learning and easy

Negative Aspect: I do not meet my friends (less socialization)

f. Question 6: Yes

g. Question 7: technical problem, for example: lecturers or students cannot share their slide when they have to present their material

h. Question 8: In order to make a friendship better, students have to communicate each other very often

3. Student 3

a. Question 1: Very much

b. Question 2: SSO and WA

c. Question 3: WA and Zoom

d. Question 4: WA is good, but not Zoom

e. Question 5:

Positive Aspect: more assignment from the lecturers and it can improve my skill and knowledge.

Negative Aspect: Lack of communication with classmates and lecturers

f. Question 6: Yes, I think

g. Question 7: time management, students joined late to a class and left earlier

h. Question 8: all students must be discipline to join the class, so that they can understand the lesson well

4. Student 4

a. Question 1: Of course

b. Question 2: Zoom, WA, SSO

c. Question 3: WA

d. Question 4: WA

e. Question 5:

Positive Aspect: No transportation fee, independent learning, self-discipline

Negative Aspect: Less communication, less interaction

f. Question 6: Yes

g. Question 7: not familiar with technology

h. Question 8: Lecturer gives group assignment, so all students will interact each other after the class

5. Student 5

a. Question 1: Yes

b. Question 2: WA and SSO

c. Question 3: WA

d. Question 4: WA

e. Question 5:

Positive Aspect: flexible time, flexible place, flexible schedule.

Negative aspect: cheating is easy when students are doing their examination, time commitment because sometimes many students join late

f. Question 6: I think so

g. Question 7: lack of interaction with other students

h. Question 8: call each other, give info, etc

From the result above, it can be seen that most of them enjoyed learning on line as long as the internet connection is good, and their internet quota is enough to join the class. The program ran well. Most lecturers use WhatsApp, Zoom and SSO (Single Sign On) of Institut Stiami and the best Media is WhatsApp, because WA is a friendly user, it easier than other medias. WA is also cheaper and better. 
The Following table is about the positive and negative aspect of on line learning (based on the students' opinion)

\begin{tabular}{|c|c|c|}
\hline No & Positive Aspect of On-Line Learning & Negative Aspect of On-Line Learning \\
\hline 1 & $\begin{array}{l}\text { Students can be more creative and } \\
\text { understand the lesson quite easier if I } \\
\text { compare with offline. }\end{array}$ & less socialization \\
\hline 2 & $\begin{array}{l}\text { It doesn't cost much, enjoyable learning and } \\
\text { easy }\end{array}$ & Less socialization \\
\hline 3 & $\begin{array}{l}\text { More assignment from the lecturers and it } \\
\text { can improve my skill and knowledge. }\end{array}$ & Lack of communication with classmates and lecturers \\
\hline 4 & $\begin{array}{l}\text { No transportation fee, independent learning, } \\
\text { self-discipline }\end{array}$ & Less communication, less interaction \\
\hline 5 & $\begin{array}{l}\text { Flexible time, flexible place, flexible } \\
\text { schedule }\end{array}$ & $\begin{array}{l}\text { cheating is easy when students are doing their } \\
\text { examination, time commitment because sometimes } \\
\text { many students join late }\end{array}$ \\
\hline
\end{tabular}

The students also mention some of the problems during on-line class and here are some problem:

1. Internet connection is up and down

2. Packet of the data is not enough

3. Technology and Technical Problem

4. Some students joined very late

5. Lack of interaction, socialization and communication

\section{CONCLUSION AND RECOMMENDATION}

Having read students' opinion, so English Learning on line during Covid 19 has positive and negative impact. Just ignore the negative impacts or make it better, and continue all the positive impacts, one of them is about continuing Learning On-Line next time if the lecturer cannot attend the class. Covid-19 has changed the world, because of Corona Virus, most lecturers and students feel the importance of digital learning, on line learning, technology, etc. Ready or not, they have to use it now.

Recommendation:

1. Do better on-line teaching and learning activities for the next semester

2. Both Lecturers and students have to learn more about technology, so there won't be any more technical problem next semester

3. Lecturers have to force all students to be able to join the class on time until the session finished

\section{BIBLIOGRAPHY}

[1]. Hartanto, W. (2016). Penggunaan E-Learning sebagai Media Pembelajaran. Jurnal Pendidikan Ekonomi,

[2]. Kemdikbud RI. (2020). Edaran Tentang Pencegahan Wabah COVID-19 di Lingkungan Satuan Pendidikan Seluruh Indonesia.

[3]. Kementerian Kesehatan. (2020). Pedoman Pencegahan dan Pengendalian Coronavirus Disease (COVID19).

[4]. Maudiarti, Santi. (2018). Penerapan E-Learning di Perguruan Tinggi. Perspektif Ilmu Pendidikan,

[5]. Simanjuntak, Lidia, et.all, E-Learning: Implementasi, Strategi dan Inovasinya, Yayasan Kita Menulis 2019 